学 会 見 解

\title{
依頼論文「歯科技工士の職場における労衝衛生管理」についての 日本補綴歯科学会としての見解
}

\author{
(公社) 日本補経歯科学会, 学術委員会, 診療ガイドライン委員会, 編集委員会 \\ Official point of view by Japan Prosthodontic Society on the invited article entitled \\ "Occupational health management in workplace of dental technicians"
}

Japan Prosthodontic Society Scientific Committee, Clinical Guideline Committee and Editorial Committee

\section{見解内容}

（公社）日本補経歯科学会を含む学術団体は，その 団体が所掌する学問あるいは周辺関連領域の理解と発 展を目指して設立されている。そのため, その領域に 関連する知識の整理や新技術の開発，今後の展望等を 主眼に講演の企画がなされてきた。加えて, 従事者を 守るための基礎知識の充実にも目を向けるようになっ てきた。たとえば感染対策はすべての医療系学術団体 にとっては必須の知識であり，特に歯科衛生士，歯科 技工士との連携が密である補経領域では，これらコデ ンタルスタッフの健康被害を避けるためにもきわめて 重要である. (公社) 日本補綴歯科学会はこれまでにも, 歯科医療安全対策推進セッションを企画して院内感染 対策について会員に対し情報提供を図っており，「補 経歯科治療過程における感染対策指針 2019$\lrcorner^{1)}$ として 電子書籍の形でとりまとめている.

2018 年 8 月付の西日本新聞に, 産業医科大学産業 生態科学研究所の森本泰夫所長が執筆された「歯科医 院でじん肺に」が揭載された ${ }^{2)}$. 要約すると, 20 代 の院内歯科技工士が入職 3 年でじん肺を発症し, 治 療法は肺移植しかなく歯科技工士を断念せざるを得な かったという内容であった。特に補綴歯科は歯科技工 と密接に関連し, 診療室でも切削等による粉塵曝露が 避けられないが，われわれはリスクをどれくらい理解 しているだろうか? 例えば国際労㗢機関は, クリスト バライトが「珪肺症その他の肺への影響, 自己免疫疾 患, 腎臓への影響, 発がん性」を有するとし, クリス トバライト埋没材の説明書には，「粉塵による人体へ の影響を避けるため，局所吸塵装置，公的機関が認可 した防塵マスクなどを使用すること，加熱によるガス
を吸入しないよう, 局所排気装置, 換気扇などを設け た部屋で作業を行うこと」が警告として赤字で明記さ れているが，有効な局所吸塵や換気が確実に実施され ているだろうか.このような情報は歯科医師，歯科技 工士にもあまり知られておらず，教育者の知識の薄さ がそのまま歯学部や歯科技工士養成機関での教育環境 にも反映されている恐机がある。

これまでに，医科や歯科領域において感染防御に関 する数多くの研究や指針が出されている，他方，「粉 塵が多量に発生する医療環境」は医科には存在せず, 歯科では補綴に関連した領域が中心となるが，本卜 ピックについての深いディスカッションはなされてい なかった。森本先生の記事は歯科医療における粉塵対 策の不備を強く指摘していたことから, 第 128 回学 術大会の歯科医療安全対策推進セッションにて,「診 療室・技工室における作業環境」という演題でご講演 いただいた。ささらに講演内容の重要性を鑑み, 今回本 誌に依頼論文として掲載する運びとなった。

本論文からは, 歯科用金属の一部に含まれるインジ ウムの著しく高いじん肺リスクや，義歯のフレーム ワーク用合金などに含有されるクロムのリスク，また 金属製補綴装置の製作，研磨に用いるクリストバライ トや研削用シリカのリスクと技工室環境の不備につい て学ぶことができる。これらの材料は，いずれも診療 室，技工室で粉塵を発生させているものである。ま た，このような現状を招いている理由として，歯科医 療環境が粉塵作業として法令（粉じん障害防止規則） に明確に規定されていないことが挙げられる。

一方で，中途半端な知識で現実に流通しているこれ らの物質を含んだ材料を忌避することは，専門家とし て適切な態度ではない。 たとえば，コントロールされ 
た HIV 感染患者を忌避するような態度が医療従事者 として不適切であることは十分理解されているはずで ある。具体例として，クリストバライト等のシリカ粉 塵はWHO の関連団体である International Agency for Research on Cancerの分類 ${ }^{3)}$ では発がん物質 (Group 1) にあたるが, 同分類で Group 1 にカテゴ ライズされるものとしては，たばこはもちろん，木屃 粉塵，日燒けマシンはおろか，アルコール飲料や果て は日光浴までが含まれる。このことは，実臨床におけ る発がん率ではなく, 発がん性の有無でグループ分け をしていることに起因する。

われわれが今後行うべきことは，歯科技工士や歯科 医師の作業環境にこのようなリスクが存在する可能性 を十分に認識し，作業環境管理に努めること，また， そのような症例に出会った際には，躊躇なく将来の歯 科界のために症例報告に努めることである。まずは， 現時点で知られているリスクを適切に把握しリスクを 低減するための適切な対応，使用している材料に対す る法規制の情報収集が不可欠であろう。そのために も，まずは本論文のご一読をお願いしたい.

\section{謝辞}

本学会見解の執筆に関しては, (公社) 日本補綴歯科学会 第 128 回学術大会の歯科医療安全対策推進セッションの座 長を努められた大阪歯科大学田中昌博教授，九州大学鮎川 保則准教授に厚く御礼を申し上げる。また，森本論文と本 学会見解の査読，編集に関わられた日本補綴歯科学会誌 大 久保力廣前編集委員長に感謝を申し上げる。

\section{文献}

1）公益社団法人日本補経歯科学会。補綴歯科治療過程にお ける感染対策指針 2019. http://www.hotetsu.com/files/ files_363.pdf [accessed 2020. 03.22].

2）森本泰夫。【産業医が診る働き方改革】 $<20>$ 歯科医院で じん肺に. 2018/07/30 付 西日本新聞朝刊. https://www. nishinippon.co.jp/item/n/438989/ [accessed 2020. 03. 22].

3) International Agency for Research on Cancer, WHO. Human cancer: Known causes and prevention by organ site. IARC monographs on the identification of carcinogenic hazards to human and handbooks of cancer prevention. https://monographs.iarc.fr/wpcontent/uploads/2019/12/OrganSitePoster.PlusHandbooks.29112019.pdf [accessed 2020. 03. 22]. 